OPEN ACCESS

Edited by: Mark Meekan

Australian Institute of Marine Science

(AIMS), Australia

Reviewed by:

Lara Marcus,

Universidad de Concepción, Chile

Lauren C. Meyer,

Flinders University, Australia

${ }^{*}$ Correspondence:

Thomas C. TinHan

tinhan@tamu.edu

Specialty section:

This article was submitted to

Marine Megafauna

a section of the journal

Frontiers in Marine Science

Received: 05 February 2021

Accepted: 21 June 2021

Published: 26 July 2021

Citation:

TinHan TC and Wells RJD (2021)

Spatial and Ontogenetic Patterns

in the Trophic Ecology of Juvenile Bull

Sharks (Carcharhinus leucas) From

the Northwest Gulf of Mexico.

Front. Mar. Sci. 8:664316.

doi: 10.3389/fmars.2021.664316

\section{Spatial and Ontogenetic Patterns in the Trophic Ecology of Juvenile Bull Sharks (Carcharhinus leucas) From the Northwest Gulf of Mexico}

\author{
Thomas C. TinHan ${ }^{1 *}$ and R. J. David Wells ${ }^{1,2}$ \\ 'Department of Marine Biology, Texas A\&M University at Galveston, Galveston, TX, United States, ${ }^{2}$ Department of Ecology \\ and Conservation Biology, Texas A\&M University, College Station, TX, United States
}

A combination of stomach content and stable isotope $\left(\delta^{13} \mathrm{C}, \delta^{15} \mathrm{~N}\right.$, and $\left.\delta^{34} \mathrm{~S}\right)$ analyses were used to characterize and examine spatiotemporal and ontogenetic trends in the feeding ecology of juvenile bull sharks (Carcharhinus leucas) captured in estuaries throughout the northwest Gulf of Mexico (GoM) between 2013 and 2016. Shark diets were dominated by fish prey taxa [>98\% index of relative importance (\%IRI)], and of those identified to the family level, two families comprised greater than $50 \% \mid \mathrm{RI}$, Mugilidae (mullets: $\sim 32 \%$ ) and Sciaenidae (drums and croakers: 27\%). Clupeidae (herrings: 14\%) and Ariidae (sea catfishes: 15\%) also contributed substantially to the diet of juvenile sharks, though consumption of Ariidae increased as consumption of Clupeidae decreased in juvenile sharks larger than 893 mm Fork Length (FL) ( 1 year old). Values of $\delta^{15} \mathrm{~N}$ increased significantly with shark size, indicating a shift toward larger or higher trophic level prey with increasing shark size. Latitudinal and temporal trends in $\delta^{13} \mathrm{C}$ and $\delta^{34} \mathrm{~S}$ suggest isotopic variation occurred in correspondence with shifts in primary producer assemblages and environmental drivers of sampled estuaries. These results highlight the importance of teleost prey resources along the freshwater-marine continuum in the diet of juvenile bull sharks, as well as the utility of natural tracers in tracking ontogenetic trends in feeding ecology.

Keywords: stable isotope analysis, stomach content analysis, elasmobranch diet, ontogenetic shifts, Gulf of Mexico (GoM)

\section{INTRODUCTION}

Bull sharks (Carcharhinus leucas) are top predators in the Gulf of Mexico (GoM), particularly in coastal habitats, where their ability to osmoregulate across a wide range of salinities allows them to inhabit brackish estuaries otherwise inaccessible to elasmobranchs with narrower salinity tolerances (Heupel and Simpfendorfer, 2011). Adult female bull sharks move seasonally into estuarine habitats to pup (give birth), where juveniles may remain for several years before transitioning to higher salinity habitats (Heupel et al., 2010). As the most abundant shark in estuaries of the northwest Gulf of Mexico (nwGoM) (Froeschke et al., 2010; Plumlee et al., 2018), and perhaps across the GoM, bull sharks may play an important role in structuring estuarine food webs via direct or indirect effects (Papastamatiou et al., 2009). Previous studies of bull shark diet have included stable isotope, 
stomach content, and fecal metabarcoding analyses (Matich and Heithaus, 2014; Tillett et al., 2014; van Zinnicq Bergmann et al., 2021), and highlight the cosmopolitan nature of their diets. Studies of bull shark stomach contents across their geographic range have shown juveniles primarily consume teleost prey from families Ariidae, Clupeidae, Mugilidae, Sciaenidae, and Carangidae, with limited consumption of benthic invertebrates (e.g., Callinectes spp.) (Clark and von Schmidt, 1965; Snelson et al., 1984; Thorburn et al., 2004; Cottrant et al., 2021). With increasing size, bull sharks expand their diet to larger, vertebrate prey such as elasmobranchs, birds, marine reptiles, and marine mammals (Tuma, 1976; Snelson et al., 1984; Cliff and Dudley, 1991; Werry et al., 2011). Such dietary shifts are thought to be driven in part by morphological changes (e.g., increased gape width, swimming speed) that allow young sharks to exploit a wider range of prey. Dietary ontogenetic shifts may also be facilitated by an ontogenetic habitat expansion from freshwater/estuarine habitat toward marine/coastal habitats, in which larger prey are more abundant (Werry et al., 2011; Belicka et al., 2012; Daly et al., 2013). Nevertheless, the reliance of bull sharks on estuaries during the juvenile stage may make them particularly susceptible to the impacts of anthropogenic alterations of these habitats, and it is difficult to predict the ecosystem level effects of these alterations without a clear understanding of how bull sharks interact with surrounding ecological communities. The trophic dynamics of bull sharks in relation to estuarine communities in the nwGoM are not well understood, with only one study published to date (Cottrant et al., 2021). Therefore, studies of top predator trophic interactions are instrumental in management efforts directed at the conservation of these taxa and ecosystems alike. Such conservation efforts have recently taken ecosystem-based approaches, which rely upon detailed information regarding species interactions, particularly in the context of food webs (e.g., predator-prey interactions) (Crowder and Norse, 2008).

The dietary composition of a consumer species or population can be better understood through the taxonomic identification of prey remains from the stomachs of those consumers (Cortés, 1997). Quantification of the abundance, mass or volume, or frequency of occurrence of prey items in consumer stomachs may further be used to estimate the relative contribution or importance of each prey taxon to consumer diets (Hyslop, 1980). However, a key limitation of stomach content analysis is that it only provides a "snapshot" of the diet of each individual sampled. For elasmobranchs, the time between feeding bouts may exceed digestion and gastric evacuation times (Cortés, 1997), which results in a substantial proportion of stomachs that are empty, or contain highly digested (i.e., degraded) prey. This approach is unsuitable for gathering dietary information over time scales greater than several days, unless a very large number of stomachs is collected in a time-stratified sampling design (Cortés, 1997). In contrast, analyses of dietary tracers such as stable isotopes (hereafter "isotopes") of carbon, nitrogen and sulfur from consumer tissues provide a time-integrated representation of the feeding ecology of a consumer (Hussey et al., 2012). While values of $\delta^{15} \mathrm{C}$ and $\delta^{15} \mathrm{~N}$ are typically utilized as indicators of primary production sources and trophic position, (respectively), $\delta^{34} S$ values are known to vary along the freshwatermarine continuum (Fry and Chumchal, 2011), and vertically in the water column. Benthic sulfate-reducing bacteria produce characteristically low values of $\delta^{34} S$ that are in turn assimilated by other benthic fauna, and as these isotopes undergo little trophic fractionation, values can therefore provide an indication of the degree to which a consumer forages in benthic vs. pelagic food webs (Peterson, 1999).

In this study, we combine stomach content analysis and dietary tracers (stable isotopes of carbon, nitrogen, and sulfur) to investigate the feeding ecology of juvenile bull sharks in estuarine nurseries from the nwGoM. Dietary composition and stable isotope data were used to investigate the influence of size (fork length; FL), capture location (Estuary), and capture date (Year, Season) on the diet and trophic interactions of juvenile bull sharks. This research contributes to our understanding of the dietary requirements of juvenile bull sharks, as well as their broader role as a potential top predator in estuarine food webs.

\section{MATERIALS AND METHODS}

\section{Sample Collection}

From May 2013-October 2016, 246 juvenile bull sharks (549$1183 \mathrm{~mm} \mathrm{FL}$ ) were collected in 7 estuaries along the nwGoM (Sabine Lake: $n=49$, Galveston Bay: $n=67$, Matagorda Bay: $n=30$, Aransas Bay: $n=69$, Corpus Christi Bay: $n=29$, Upper Laguna Madre Bay: $n=1$, and Lower Laguna Madre Bay: $n=1$ ) (Figure 1). Sharks sampled were incidental mortalities occurring in Texas Parks and Wildlife Department gill net surveys (Martinez-Andrade et al., 2009) conducted in the spring (April-June) and fall (August-November). Prior to processing, each shark was stored frozen $\left(-20^{\circ} \mathrm{C}\right)$. Upon processing, sharks were thawed, measured (FL), sexed, and stomachs and $\sim 100 \mathrm{~g}$ of epaxial (hereafter "muscle") tissue were removed. Stomachs were preserved in $10 \%$ formalin for $48 \mathrm{~h}$ and subsequently stored in $70 \%$ ethyl alcohol. Upon removal, muscle tissue was stored $\left(-20^{\circ} \mathrm{C}\right)$ until subsequent stable isotope analysis (TinHan, 2020). Stable isotope analyses were performed on tissue from a subset of 138 sharks selected to maximize the balance of sample sizes across years, seasons, estuaries and shark sizes (Supplementary Table 1). Due to lack of replication, stable isotope analyses were not performed for sharks from Upper and Lower Laguna Madre Bays.

\section{Stomach Content Analysis}

The contents of preserved stomachs were separated across three sieves (mesh widths: 1.27, 0.14, and $0.05 \mathrm{~cm}$ ), rinsed and the combined wet weight of all contents was recorded. All contents were identified to the lowest possible taxon, sorted, weighed (to the nearest $0.001 \mathrm{~g}$ ), and where possible, the number of individual prey items was recorded. Three metrics of dietary composition were estimated from stomach contents: percent frequency of occurrence $(\% \mathrm{FO})$, percent number $(\% \mathrm{~N})$, and percent weight $(\% \mathrm{~W}) . \% \mathrm{FO}$ was calculated as the number of stomachs containing each prey taxon, divided by the total number of stomachs containing prey. $\% \mathrm{~N}$ was calculated as the number of individual 


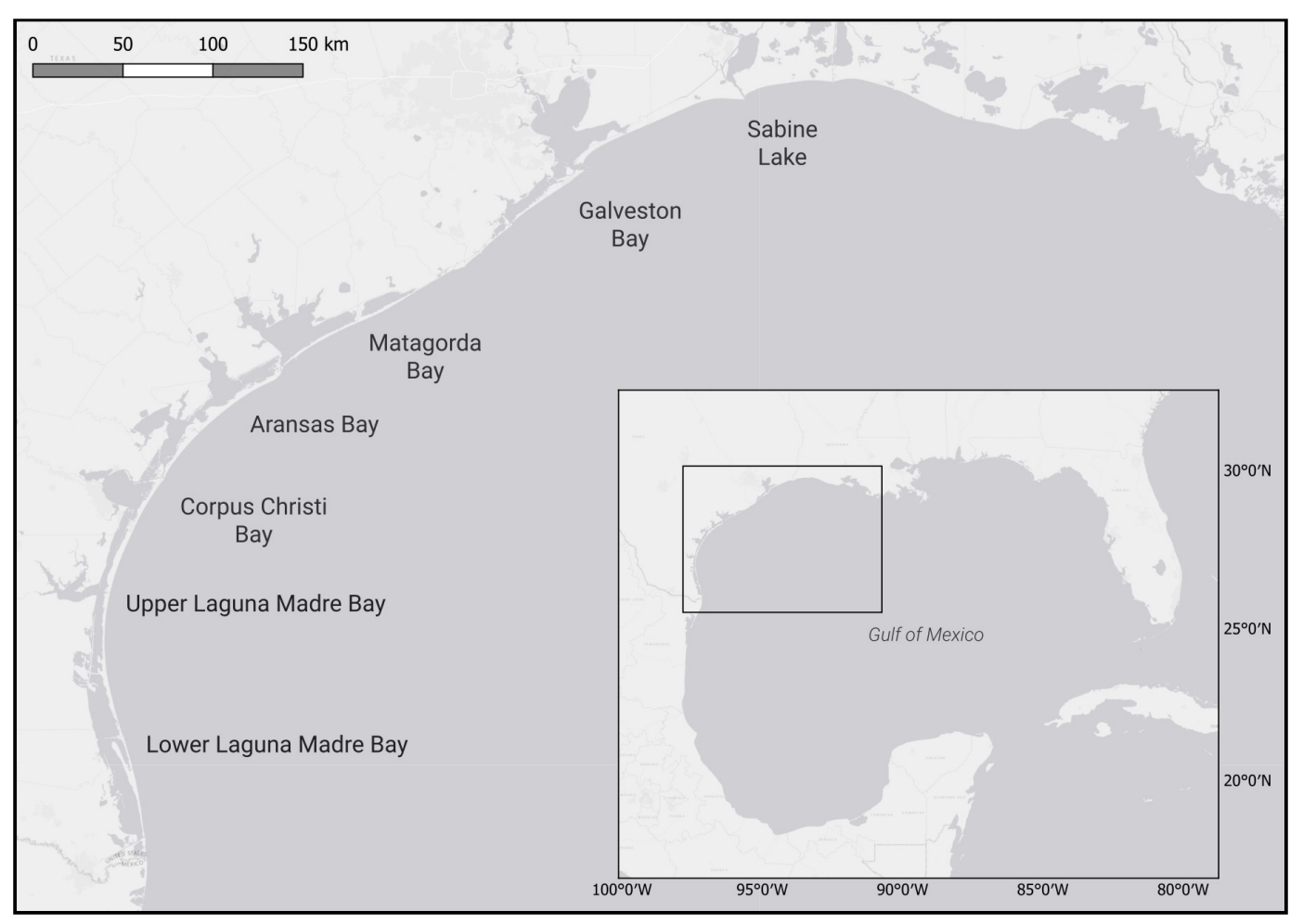

FIGURE 1 | Map of northwest Gulf of Mexico (nwGoM) estuaries from which juvenile bull sharks were collected. Box shows location of estuaries within Gulf of Mexico (GoM).

prey items in each taxon, divided by the total of all individual prey items in each stomach. $\% W$ was calculated as the mass of each prey taxon divided by the total mass of all prey taxa by stomach. While the proportion of sharks with empty stomachs was recorded, these samples were not considered informative for examining dietary composition and they were therefore omitted from dietary metric calculations. To obtain estimates of variability around $\% N$ and $\% W$, these were calculated for each sample (Bizzarro et al., 2007). A composite dietary index, the index of relative importance (IRI) (Pinkas et al., 1971) was similarly, calculated for each prey category in each sample

$$
I R I_{i, j}=\% F O_{i} \times\left(\% W_{i, j}+\% N_{i}, j\right)
$$

and converted to \%IRI:

$$
\% I R I_{i, j}=\frac{I R I_{i, j}}{\sum_{i=1}^{n_{j}}\left(I R I_{i, j}\right)}
$$

where $i$ represents each prey taxon in sample stomach $j$, and $n$ represents the total number of prey taxa in $J$. Due to the preponderance of fish in bull shark stomachs, dietary metrics were also calculated at the family level (or order, where familylevel identification was not possible) for fish prey, under the assumption that identified fish were representative of all fish prey (unidentified and identified). Relationships between each dietary composition metric $(\% \mathrm{~N}, \% \mathrm{~W}, \% \mathrm{IRI})$ and predictor variables [shark size (FL), capture location (Estuary), and capture year (Year)], were tested using permutational analysis of variance (PERMANOVA; function adonis2 in $\mathrm{R}$ package vegan). Dietary composition metrics ( $\% \mathrm{~N}, \% \mathrm{~W}, \% \mathrm{IRI})$ were square root transformed, and analyzed against FL and Estuary. Ontogenetic trends in stomach contents were examined by pooling sharks (for which stomach contents were analyzed) into size classes. The number $(N=2)$ and ranges (small: 549892, large: 893-1183 $\mathrm{mm}$ FL) of these classes were defined by an equal-variance hierarchical clustering model ( $\mathrm{R}$ package $m c l u s t)$. Spatial patterns were examined by pooling sharks into two regional groups based on location of capture: (1) northern (Sabine Lake, Galveston Bay), and (2) southern (Matagorda, Aransas, Corpus Christi Bays) estuaries. Shark size was also compared against the binomial probability of a stomach being empty or containing prey (logistic regression), as well as percent fullness ( mass $_{\text {stomachcontents }} /$ mass $_{\text {shark }} \times 100$ ) (linear regression).

\section{Stable Isotope Analysis}

Muscle tissue samples were oven dried at $60^{\circ} \mathrm{C}$, and lipid extracted using non-polar petroleum ether solvent in a Dionex 350 Accelerated Solvent Extractor (ThermoFisher Scientific Inc.) following (Plumlee and Wells, 2016). Lipid-extracted samples were then homogenized with a ball/vial grinder (Wig-L-Bug; Sigma-Aldrich Co., LLC), and $\sim 1 \mathrm{mg}$ of material was transferred into $5 \times 9 \mathrm{~mm}$ tin capsules for analysis at the University of California, Davis Stable Isotope Facility. Samples were then analyzed for ${ }^{13} \mathrm{C}:{ }^{12} \mathrm{C}$ and ${ }^{15} \mathrm{~N}:{ }^{14} \mathrm{~N}$ isotope ratios on a 
PDZ Europa ANCA-GSL elemental analyzer and PDZ Europa 20-20 isotope ratio mass spectrometer (IRMS; Sercon Ltd., Cheshire, United Kingdom). Analysis of ${ }^{34} \mathrm{~S}:{ }^{32} \mathrm{~S}$ isotope ratios was conducted on an Elementar vario ISOTOPE cube and SerCon 20-22 IRMS (Sercon Ltd.). Results are reported in delta notation, relative to standards Vienna Pee Dee Belemnite (carbon), air (nitrogen), and Vienna Canyon Diablo Troilite (sulfur), using the following equation:

$$
\delta X(\%)=\left[\frac{R_{\text {sample }}}{R_{\text {standard }}}-1\right] \times 100
$$

where $R$ is the ratio of heavy to light isotopes of element $X$ in the sample or standard reference material. The main effects of shark size (FL), capture year (Year), capture season (Season; Spring and Fall), and capture location (Estuary) upon isotope values were modeled using generalized least squares with Helmert contrasts (R package car). No sharks were collected from Corpus Christi Bay in 2013 or Matagorda Bay in 2014, so Type I Sums of Squares ANOVAs were used to evaluate Year:Estuary interactions. To account for ontogenetic shifts in evaluations of interaction terms, FL was included as a covariate. Pairwise regressions of isotopes were performed using robust linear regression analysis via function lmrob in R package robustbase (Rousseeuw et al., 2015).

\section{RESULTS}

\section{Stomach Content Analysis}

Of 223 juvenile bull shark stomachs examined, 171 (77\%) contained identifiable prey items $(N=561)$. Shark size was not found to have any relationship with the probability of a stomach containing prey (logistic regression; $p>0.05$ ), nor percent fullness (linear regression; $p>0.05$ ). Prey items were identified to 38 unique taxa (lowest taxonomic level), approaching the mean estimate of asymptotic prey richness $\left(S_{\text {Chao }}=45.0 \pm 9.4\right.$; mean $\pm 95 \%$ CI, Figure 2A). Stomachs contained prey items from three broad categories: (1) fishes, (2) invertebrates, and (3) vegetation. Thirteen taxa (34\%) identified from stomachs were invertebrates (arthropods and molluscs) and vegetation (plants and algae), while the remaining taxa were fishes (chondrichthyans and teleosts), composing $>95 \%$ of the diet of juvenile bull sharks, by all dietary metrics (Tables 1, 2). Unidentified teleosts were the most commonly encountered prey across juvenile bull sharks (79\% FO), representing $67 \pm 40 \%$ (mean \pm SD) of prey by numerical abundance $(\% \mathrm{~N})$ and $68 \pm 44 \%$ by weight (\%W). Further, unidentified teleosts were the most important (\%IRI) prey category in juvenile bull shark diets (77 $\pm 40 \%$ ), followed by Mugil spp. (4.4 $\pm 16.9 \%)$. Fish prey were identified to 11 families/orders, approaching the estimated asymptotic family/order prey richness $\left(S_{\text {Chao }}=12.0 \pm 3.6\right.$; Figure 2B). Of the 11 fish taxa identified to family/order, four families were substantially $(>4 \mathrm{x})$ greater in importance than all other taxa: (1) Mugilidae (mullets; $31.6 \pm 43.0 \%$ ), (2) Sciaenidae (drums and croakers; $26.9 \pm 42.9 \%$ ), (3) Ariidae (sea catfishes; $15.0 \pm 35.0 \%$ ), and (4) Clupeidae (herrings; $14.4 \pm 31.1 \%)$. The rank-order importance of these four families in the diets of juvenile bull sharks remained almost unchanged across the remaining three dietary metrics, with the exception of increased representation of Clupeidae relative to Ariidae in $\% \mathrm{~W}$ and \%FO (Table 2). Due to the high variability in dietary composition across individuals, no significant relationships were found between dietary composition and shark size, capture location, or capture year $(p>0.05)$. However, some qualitative patterns emerged when sharks were broken into two size classes ( $<$ or $>893 \mathrm{~mm} \mathrm{FL}$ ); the most important prey families (\%IRI) in both large and small sharks were Sciaenidae, Mugilidae, and Ariidae. However, the importance of Ariidae was greater in the diet of large sharks (23.6\%) relative to small sharks (7.5\%). Likewise, the importance of Clupeidae was less for large sharks $(8.3 \%)$ relative to that of small sharks $(16.5 \%)$.

\section{Stable Isotope Analysis}

All three isotopes varied significantly with shark size (FL), with the greatest effect seen in values of $\delta^{15} \mathrm{~N}\left(F_{1,128}=27.38\right.$, $p<0.001)$, which increased with FL. Values of $\delta^{13} \mathrm{C}$ and $\delta^{34} \mathrm{~S}$ showed weaker, negative relationships with shark size $\left(\delta^{13} \mathrm{C}\right.$ : $F_{1,128}=10.11, p=0.002 ; \delta^{34} S: F_{1,128}=6.99, p=0.009$ ) (Figure 3 and Table 3). The disparity in $\delta^{13} \mathrm{C}$ values between northern estuaries (Sabine Lake, Galveston Bay) and southern estuaries (Matagorda, Aransas, Corpus Christi Bays) increased from 2013 to 2016 (Figure 4A), though differences across years in $\delta^{13} \mathrm{C}$ and $\delta^{15} \mathrm{~N}$ were not significant $\left(\delta^{13} \mathrm{C}: p=0.112 ; \delta^{15} \mathrm{~N}: p=0.056\right)$. Slight variation in $\delta^{34} S$ was observed with respect to year $\left(\delta^{34} S\right.$ : $F_{3,128}=4.95, p=0.003$; Table 3 ), and variation among individuals in Galveston Bay increased from 2013 to 2016 (Figure 4C). Values of $\delta^{13} \mathrm{C}$ were significantly different between seasons $\left(F_{4,128}=6.28\right.$, $p=0.014)$, with $\delta^{13} \mathrm{C}$ values being slightly higher in the spring than in the fall, though this trend was not consistent among years and estuaries (Supplementary Figure 1). Values of $\delta^{13} \mathrm{C}$ exhibited a clear latitudinal trend among estuaries $\left(F_{4,128}=31.53\right.$, $p<0.001$ ), with values increasing from north to south. Significant, albeit slight, differences were observed in $\delta^{15} \mathrm{~N}$ values among estuaries $\left(F_{4,128}=0.08, p<0.001\right)$, and values in sharks from Galveston Bay were elevated relative to those from other sampled estuaries (Galveston Bay, mean \pm SD: $17.5 \pm 1.7 \%$; all other estuaries: $15.4 \pm 1.2 \%$; Figure 4B). Though $\delta^{34} \mathrm{~S}$ values varied significantly among estuaries $(p=0.003)$, no latitudinal trend was apparent (Figure 4C). There was a significant negative relationship between $\delta^{13} \mathrm{C}$ and $\delta^{15} \mathrm{~N}\left(r^{2}=0.17, p<0.001\right)$, though $\delta^{34} \mathrm{~S}$ values were uncorrelated to $\delta^{15} \mathrm{~N}$ or $\delta^{13} \mathrm{C}(p>0.05$; Figure 5 and Table 4).

\section{DISCUSSION}

In this study, we characterized the diet and trophic dynamics of juvenile bull sharks from the nwGoM using a combination of stomach content and stable isotope analyses. Asymptotic prey richness was not reached in identifications of prey to the lowest possible taxon, potentially owing to the heavily digested state of most prey items, and the subsequent difficulty of identifying such items to genus or species. However, juvenile bull shark diets consisted almost exclusively of teleost prey, which is in 

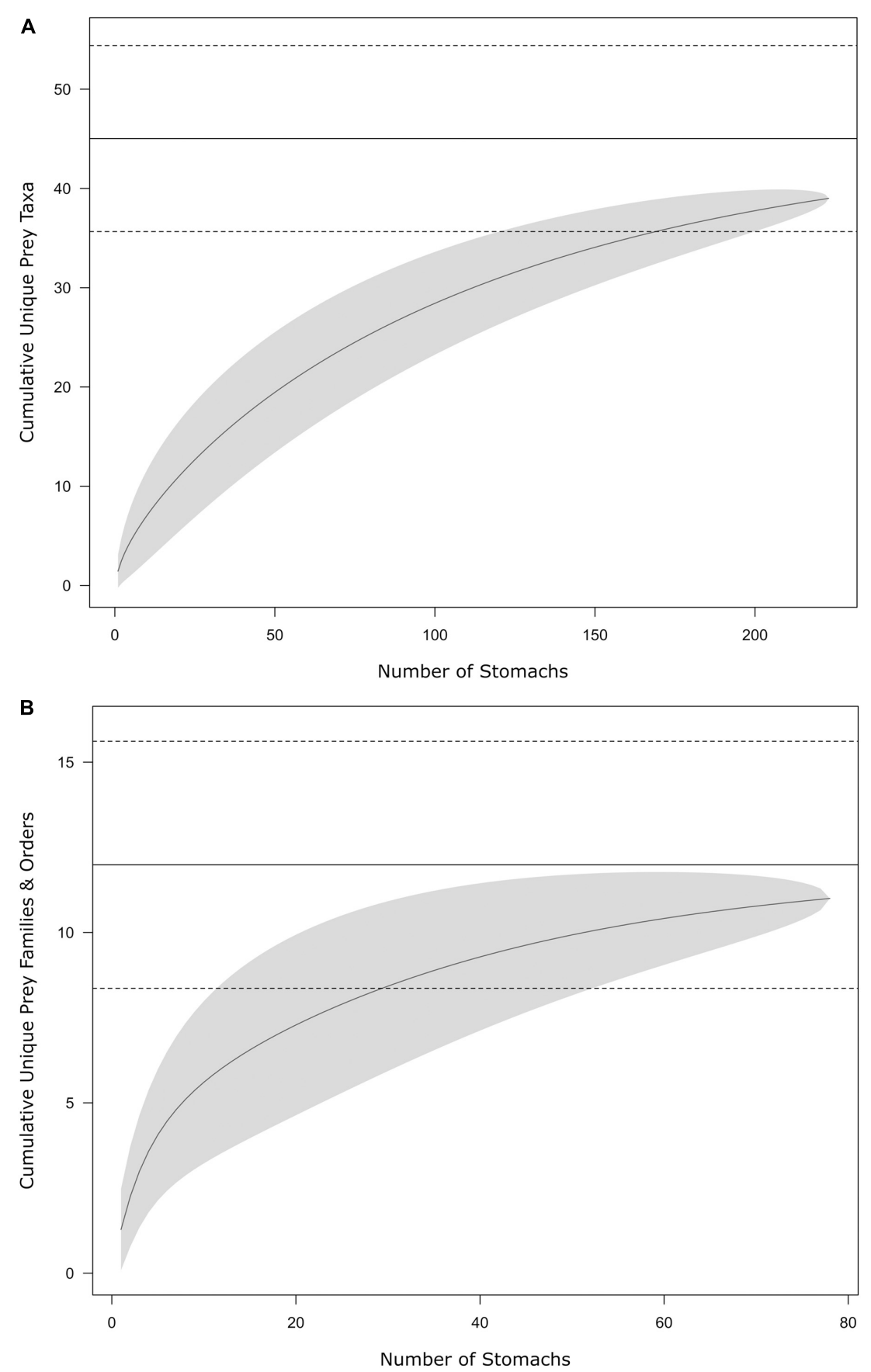

FIGURE 2 | Cumulative prey curves of the diet of juvenile bull sharks from nwGoM estuaries for prey identified to (A) the lowest possible taxon and (B) family level or higher. Horizontal solid lines represent estimated mean asymptotic prey richness $\pm 95 \%$ confidence intervals (dotted lines) against the number of stomachs examined. Solid curve lines represent mean prey richness. Shaded contours represent $95 \%$ confidence intervals of prey richness.

accord with previous dietary studies of juvenile bull sharks from across their range (Sadowsky, 1971; Tuma, 1976; Snelson et al., 1984; Werry et al., 2011; Tillett et al., 2014; Trystram et al., 2016). A small proportion of analyzed stomachs also contained invertebrates and vegetation, and while it is possible invertebrates were specifically targeted for consumption, the majority of stomachs containing vegetation also contained fish or invertebrates. This suggests vegetation might have been incidentally ingested while foraging among habitats containing aquatic plants or algae. One coastal shark species (bonnethead, Sphyrna tiburo) is capable of digesting and assimilating seagrass (Leigh et al., 2018); however, it is unclear whether consumption is incidental, and whether other elasmobranchs are also capable of omnivory. Nevertheless, these items were neither abundant 
TABLE 1 | Dietary composition of bull sharks (Carcharhinus leucas) from nwGoM estuaries expressed as percent frequency of occurrence (\%FO), percent number $(\% N)$, percent weight $(\% W)$, and percent index of relative importance $(\% / R I)$ for prey identified to the lowest taxonomic level.

\begin{tabular}{|c|c|c|c|c|}
\hline Prey Taxon & $\% F O$ & $\overline{\% \mathbf{N}} \pm \mathbf{S D}$ & $\overline{\% \mathbf{W}} \pm \mathbf{S D}$ & $\overline{\% \mathbf{I R I}} \pm \mathbf{S D}$ \\
\hline Fishes & 98.82 & $95.29 \pm 15.04$ & $97.65 \pm 13.7$ & $98.52 \pm 10.91$ \\
\hline Myliobatiformes & 2.96 & $1.57 \pm 11.25$ & $1.87 \pm 12.48$ & $1.63 \pm 11.96$ \\
\hline \multicolumn{5}{|l|}{ Elopidae } \\
\hline Elops saurus & 1.18 & $1.18 \pm 10.85$ & $1.18 \pm 10.85$ & $1.18 \pm 10.85$ \\
\hline Anguilliformes & 0.59 & $0.15 \pm 1.92$ & $0.58 \pm 7.49$ & $0.01 \pm 0.09$ \\
\hline Ophichthidae & 1.18 & $0.27 \pm 2.73$ & $0.07 \pm 0.73$ & $0.08 \pm 0.98$ \\
\hline Ophichthus gomesii & 0.59 & $0.59 \pm 7.69$ & $0.59 \pm 7.69$ & $0.59 \pm 7.69$ \\
\hline Clupeidae & 4.14 & $1.66 \pm 9.81$ & $3.18 \pm 16.29$ & $1.77 \pm 10.66$ \\
\hline Brevoortia patronus & 2.96 & $1.65 \pm 11.36$ & $2.72 \pm 15.83$ & $1.48 \pm 11.26$ \\
\hline Dorosoma cepedianum & 1.78 & $1.78 \pm 13.24$ & $1.78 \pm 13.24$ & $1.78 \pm 13.24$ \\
\hline Ariidae & 7.10 & $2.91 \pm 12.41$ & $2.5 \pm 13.76$ & $1.55 \pm 9.37$ \\
\hline Ariopsis felis & 1.18 & $1.18 \pm 10.85$ & $1.18 \pm 10.85$ & $1.18 \pm 10.85$ \\
\hline Batrachoididae & 1.18 & $0.32 \pm 2.98$ & $0.29 \pm 2.89$ & $0.12 \pm 1.59$ \\
\hline \multicolumn{5}{|l|}{ Mugilidae } \\
\hline Mugil cephalus & 2.37 & $1.87 \pm 13.29$ & $1.81 \pm 13.25$ & $1.78 \pm 13.24$ \\
\hline Mugil curema & 0.59 & $0.1 \pm 1.28$ & $0.46 \pm 5.92$ & $0.01 \pm 0.09$ \\
\hline Mugil spp. & 15.38 & $5.73 \pm 17.57$ & $4.73 \pm 19.75$ & $4.33 \pm 16.89$ \\
\hline \multicolumn{5}{|l|}{ Moronidae } \\
\hline Morone chrysops & 0.59 & $0.3 \pm 3.85$ & $0.54 \pm 7.06$ & $0.01 \pm 0.14$ \\
\hline Sparidae & 1.78 & $0.56 \pm 4.68$ & $0.62 \pm 6.26$ & $0.34 \pm 4.25$ \\
\hline Sciaenidae & 1.78 & $0.64 \pm 4.98$ & $0.2 \pm 2.56$ & $0.01 \pm 0.1$ \\
\hline Bairdiella chrysoura & 1.78 & $0.48 \pm 4.21$ & $0 \pm 0.03$ & $0.01 \pm 0.06$ \\
\hline Cynoscion arenarius & 1.78 & $0.84 \pm 8.01$ & $1.71 \pm 12.79$ & $0.63 \pm 7.7$ \\
\hline Cynoscion nebulosus & 1.18 & $1.18 \pm 10.85$ & $1.18 \pm 10.85$ & $1.18 \pm 10.85$ \\
\hline Cynoscion spp. & 5.33 & $2.18 \pm 10.74$ & $1.51 \pm 9.99$ & $1.42 \pm 9.69$ \\
\hline Menticirrhus americanus & 0.59 & $0.15 \pm 1.92$ & $0.35 \pm 4.53$ & $0 \pm 0.04$ \\
\hline Micropogonias undulatus & 2.37 & $0.76 \pm 5.32$ & $0.85 \pm 8.12$ & $0.24 \pm 2.31$ \\
\hline Sciaenops ocellatus & 0.59 & $0.2 \pm 2.56$ & $0.4 \pm 5.23$ & $0 \pm 0.06$ \\
\hline Teleostei (unidentified) & 78.70 & $67.05 \pm 40.19$ & $67.35 \pm 44.07$ & $77.01 \pm 40.44$ \\
\hline Invertebrates & 8.28 & $2.16 \pm 7.97$ & $0.58 \pm 4.14$ & $0.25 \pm 1.47$ \\
\hline \multicolumn{5}{|l|}{ Arthropoda } \\
\hline Isopoda & 0.59 & $0.08 \pm 1.1$ & $0 \pm 0$ & $0 \pm 0.01$ \\
\hline Decapoda & 1.18 & $0.32 \pm 2.98$ & $0.04 \pm 0.5$ & $0.03 \pm 0.31$ \\
\hline Penaeidae & 1.78 & $0.38 \pm 3.03$ & $0.02 \pm 0.16$ & $0.03 \pm 0.36$ \\
\hline Caridea & 0.59 & $0.07 \pm 0.96$ & $0.09 \pm 1.22$ & $0 \pm 0.02$ \\
\hline Paguridae & 0.59 & $0.12 \pm 1.54$ & $0.1 \pm 1.31$ & $0.01 \pm 0.17$ \\
\hline Brachyura & 1.18 & $0.27 \pm 2.73$ & $0.28 \pm 2.74$ & $0.1 \pm 1.23$ \\
\hline \multicolumn{5}{|l|}{ Hexapoda } \\
\hline Apidae & 0.59 & $0.07 \pm 0.96$ & $0 \pm 0$ & $0 \pm 0$ \\
\hline Vespidae & 0.59 & $0.15 \pm 1.92$ & $0 \pm 0.03$ & $0 \pm 0.01$ \\
\hline Mollusca & 1.18 & $0.39 \pm 4.05$ & $0.03 \pm 0.37$ & $0 \pm 0.05$ \\
\hline Bivalvia & 1.18 & $0.3 \pm 2.71$ & $0.02 \pm 0.23$ & $0.05 \pm 0.44$ \\
\hline Vegetation & 6.51 & $2.55 \pm 11.64$ & $1.77 \pm 12.97$ & $1.23 \pm 11.04$ \\
\hline Angiospermae & 4.14 & $1.85 \pm 10.3$ & $1.17 \pm 10.52$ & $1.15 \pm 10.2$ \\
\hline Halodule wrightii & 1.78 & $0.32 \pm 2.49$ & $0.02 \pm 0.24$ & $0.05 \pm 0.57$ \\
\hline Algae & 1.18 & $0.38 \pm 3.99$ & $0.58 \pm 7.44$ & $0.23 \pm 2.92$ \\
\hline
\end{tabular}

$\% N, \% W$, and $\% I R I$ were calculated for each stomach in order to allow estimation of the means and standard deviations of each metric. Bolded values represent pooled estimates for each major prey taxon.

nor frequently encountered in this study, and are therefore not expected to be an important component of the diet of juvenile bull sharks in Texas. Elasmobranchs were similarly, rare, and only present in just three of the 171 stomachs that contained
TABLE 2 | Contributions of fish prey identified to family (or higher, where family-level identification was not possible) to the diet of bull sharks (Carcharhinus leucas) from nwGoM estuaries.

\begin{tabular}{|c|c|c|c|c|c|}
\hline Size Class & Prey Taxon & $\% F O$ & $\overline{\% \mathbf{N}} \pm \mathbf{S D}$ & $\overline{\% \mathbf{W}} \pm \mathbf{S D}$ & $\overline{\% \mathbf{I R I}} \pm \mathbf{S D}$ \\
\hline \multirow{11}{*}{$\begin{array}{l}\text { All sharks } \\
(549-1183 \mathrm{~mm} \\
\text { FL) }\end{array}$} & Myliobatiformes & 5.2 & $3.3 \pm 16.5$ & $3.3 \pm 17.0$ & $3.3 \pm 17.1$ \\
\hline & Elopidae & 2.6 & $2.6 \pm 15.9$ & $2.6 \pm 15.9$ & $2.6 \pm 15.9$ \\
\hline & Anguilliformes & 1.3 & $1.3 \pm 11.3$ & $1.3 \pm 11.3$ & $1.3 \pm 11.3$ \\
\hline & Ophichthidae & 3.9 & $2.0 \pm 12.1$ & $1.5 \pm 11.4$ & $1.6 \pm 11.5$ \\
\hline & Clupeidae & 19.5 & $12.9 \pm 29.4$ & $18.8 \pm 38.7$ & $14.4 \pm 31.1$ \\
\hline & Ariidae & 18.2 & $15.5 \pm 35.2$ & $14.9 \pm 35.2$ & $15.0 \pm 35.0$ \\
\hline & Batrachoididae & 2.6 & $1.1 \pm 6.8$ & $0.7 \pm 4.4$ & $0.3 \pm 2.5$ \\
\hline & Mugilidae & 39.0 & $31.1 \pm 42.1$ & $26.5 \pm 43.3$ & $31.6 \pm 43.0$ \\
\hline & Moronidae & 1.3 & $1.3 \pm 11.3$ & $1.3 \pm 11.3$ & $1.3 \pm 11.3$ \\
\hline & Sparidae & 3.9 & $2.4 \pm 13.1$ & $3.7 \pm 18.4$ & $1.8 \pm 11.7$ \\
\hline & Sciaenidae & 31.2 & $26.7 \pm 42.4$ & $25.7 \pm 42.9$ & $26.9 \pm 42.9$ \\
\hline \multirow{11}{*}{$\begin{array}{l}\text { Small sharks } \\
\text { (549-892 mm } \\
\text { FL) }\end{array}$} & Myliobatiformes & 1.7 & $1.7 \pm 12.9$ & $1.7 \pm 12.9$ & $1.7 \pm 12.9$ \\
\hline & Elopidae & 3.3 & $3.3 \pm 18.1$ & $3.3 \pm 18.1$ & $3.3 \pm 18.1$ \\
\hline & Anguilliformes & 1.7 & $1.7 \pm 12.9$ & $1.7 \pm 12.9$ & $1.7 \pm 12.9$ \\
\hline & Ophichthidae & 3.3 & $2.0 \pm 13.1$ & $1.8 \pm 12.9$ & $1.7 \pm 12.9$ \\
\hline & Clupeidae & 21.7 & $14.7 \pm 30.8$ & $21.2 \pm 40.7$ & $16.5 \pm 32.8$ \\
\hline & Ariidae & 16.7 & $14.7 \pm 34.6$ & $14.2 \pm 34.6$ & $14.2 \pm 34.3$ \\
\hline & Batrachoididae & 1.7 & $0.8 \pm 6.5$ & $0.3 \pm 2.2$ & $0.0 \pm 0.3$ \\
\hline & Mugilidae & 41.7 & $32.2 \pm 42.0$ & $26.0 \pm 42.8$ & $32.5 \pm 42.9$ \\
\hline & Moronidae & 1.7 & $1.7 \pm 12.9$ & $1.7 \pm 12.9$ & $1.7 \pm 12.9$ \\
\hline & Sparidae & 3.3 & $2.2 \pm 13.5$ & $3.3 \pm 17.8$ & $1.9 \pm 13.0$ \\
\hline & Sciaenidae & 28.3 & $25.0 \pm 41.8$ & $24.9 \pm 42.3$ & $25.0 \pm 41.9$ \\
\hline \multirow{11}{*}{$\begin{array}{l}\text { Large sharks } \\
\text { (893-1183 mm } \\
\text { FL) }\end{array}$} & Myliobatiformes & 17.7 & $9.3 \pm 25.3$ & $9.2 \pm 27.0$ & $10.8 \pm 28.7$ \\
\hline & Elopidae & - & - & - & - \\
\hline & Anguilliformes & - & - & - & - \\
\hline & Ophichthidae & 5.9 & $2.0 \pm 8.1$ & $0.5 \pm 2.2$ & $0.7 \pm 2.7$ \\
\hline & Clupeidae & 11.8 & $7.4 \pm 24.6$ & $11.1 \pm 31.5$ & $8.2 \pm 25.5$ \\
\hline & Ariidae & 23.5 & $19.1 \pm 39.1$ & $18.1 \pm 39.1$ & $19.0 \pm 39.1$ \\
\hline & Batrachoididae & 5.9 & $2.0 \pm 8.1$ & $2.1 \pm 8.6$ & $1.1 \pm 4.4$ \\
\hline & Mugilidae & 29.4 & $23.0 \pm 40.4$ & $23.7 \pm 43.6$ & $23.7 \pm 41.2$ \\
\hline & Moronidae & - & - & - & - \\
\hline & Sparidae & 5.9 & $2.9 \pm 12.1$ & $5.2 \pm 21.6$ & $1.4 \pm 5.9$ \\
\hline & Sciaenidae & 41.2 & $34.3 \pm 45.8$ & $30.1 \pm 46.6$ & $35.1 \pm 46.9$ \\
\hline
\end{tabular}

Contributions are expressed as \%FO, percent frequency of occurrence; $\% \mathrm{~N}$, percent number; \%W, percent weight; \%IRI, percent index of relative importance. $\% \mathrm{~N}, \% \mathrm{~W}$, and $\% I R I$ were calculated for each stomach to allow estimation of the means and standard deviations of each metric. Metrics are also reported for two size classes as defined by shark FL.

prey. Identifications of fish prey to family (or higher) approached asymptotic prey richness, which suggests that, although there may have been specific genera or species overlooked in our sampling, greater sampling was not likely to identify additional prey families. Just two fish families (Mugilidae and Sciaenidae) contributed to greater than $50 \%$ of the diet of juvenile bull sharks, though Ariidae and Clupeidae were also important components of their diet. In contrast to \%IRI, the relative contribution of 


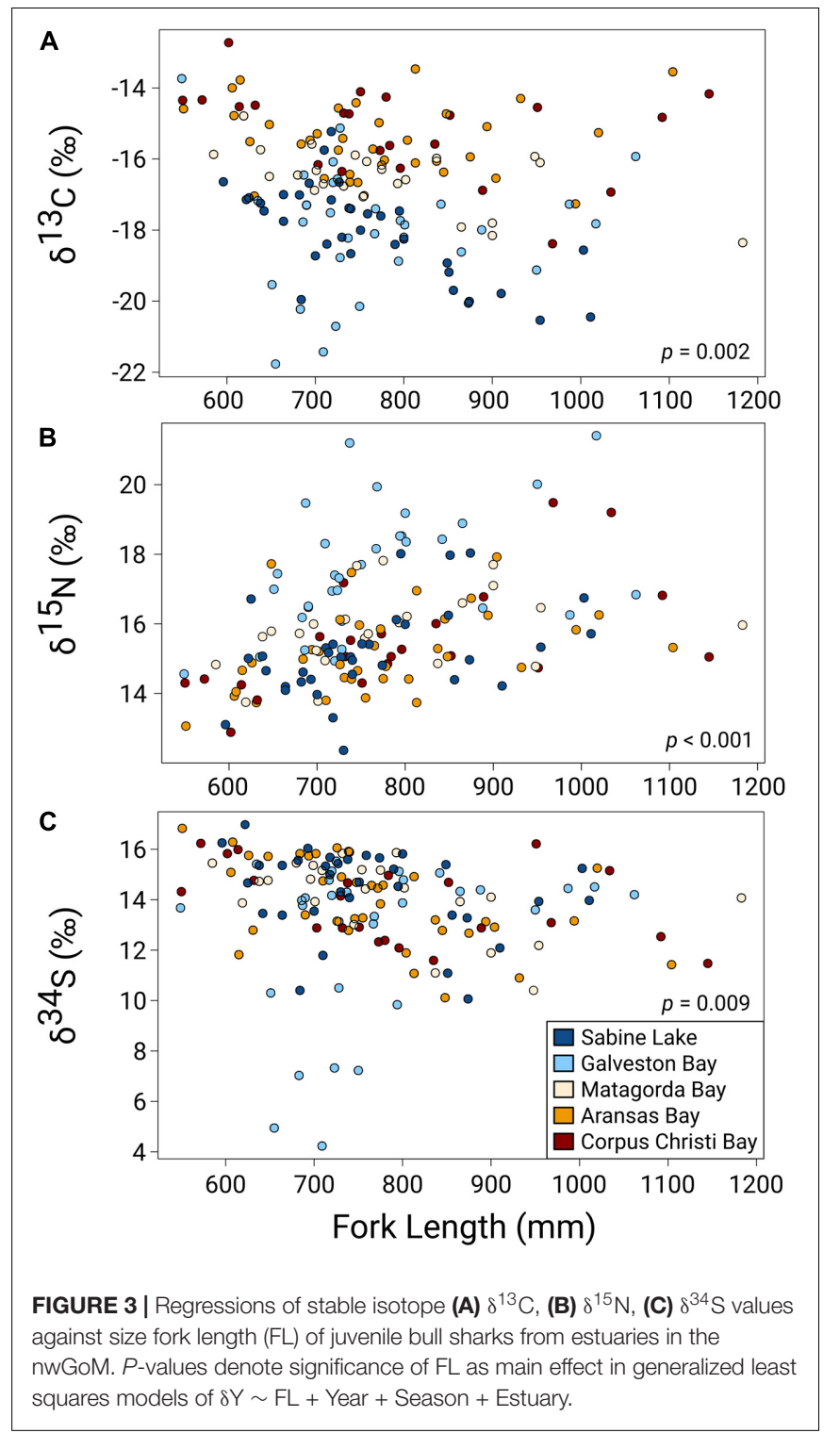

Clupeidae to bull shark diet increased when expressed in terms of $\% \mathrm{~W}$ and $\% \mathrm{FO}$. Similarly, the relative contribution of Ariidae decreased when using these metrics, rather than \%IRI. This may be due to inherent differences in the digestibility of ariid $\mathrm{v}$. clupeid prey, as well as the presence of conspicuous structures in ariids by which they are easily identified (barbed first-dorsal and pectoral fin spines), whereas clupeids were usually only observed in stomachs with relatively undigested contents. Recent work by Cottrant et al. (2021) utilizing both stomach content analyses and a literature review identified these four families as the most commonly encountered in juvenile bull shark diets from San Antonio Bay, Texas, and among the most common in juvenile and adult bull shark diets published elsewhere. Biases introduced by digestion rates or identifiability may therefore be minimal, or are more likely consistent across studies.

Bull sharks spend the first several years of life in coastal nurseries, during which they may more than double in size.
TABLE 3 | Model results showing main effects of shark size (FL), capture year (Year), capture season (Season), capture location (Estuary), and interactive effect of Year:Estuary on stable isotope values obtained from juvenile bull shark muscle tissue.

\begin{tabular}{lcccc}
\hline Tracer & Variable & D.F & $\boldsymbol{F}$-value & $\boldsymbol{p}$-value \\
\hline$\delta^{13} \mathrm{C}$ & FL & $\mathbf{1 , 1 2 8}$ & $\mathbf{1 0 . 1 1}$ & $\mathbf{0 . 0 0 2}$ \\
& Year & 3,128 & 2.04 & 0.112 \\
& Season & $\mathbf{1 , 1 2 8}$ & $\mathbf{6 . 2 8}$ & $\mathbf{0 . 0 1 4}$ \\
& Estuary & $\mathbf{4 , 1 2 8}$ & $\mathbf{3 1 . 5 3}$ & $<\mathbf{0 . 0 0 1}$ \\
& Year:Estuary & 10,128 & 1.18 & 0.304 \\
$\delta^{15} N$ & FL & $\mathbf{1 , 1 2 8}$ & $\mathbf{2 7 . 3 8}$ & $<\mathbf{0 . 0 0 1}$ \\
& Year & 3,128 & 4.39 & 0.056 \\
& Season & $\mathbf{1 , 1 2 8}$ & 3.72 & 0.777 \\
& Estuary & $\mathbf{4 , 1 2 8}$ & $\mathbf{0 . 0 8}$ & $<\mathbf{0 . 0 0 1}$ \\
& Year:Estuary & 10,128 & 1.31 & 0.235 \\
$\delta^{34} S$ & FL & $\mathbf{1 , 1 2 8}$ & $\mathbf{6 . 9 9}$ & $\mathbf{0 . 0 0 9}$ \\
& Year & $\mathbf{3 , 1 2 8}$ & $\mathbf{4 . 9 5}$ & $\mathbf{0 . 0 0 3}$ \\
& Season & $\mathbf{1 , 1 2 8}$ & 3.72 & 0.056 \\
& Estuary & $\mathbf{4 , 1 2 8}$ & $\mathbf{5 . 1 1}$ & $<\mathbf{0 . 0 0 1}$ \\
& Year:Estuary & 10,128 & 1.27 & 0.255 \\
\hline
\end{tabular}

Main effects were modeled using generalized least squares with Helmert contrasts. Interaction terms were tested in Type I Sums of Squares ANOVA. Significant terms indicated in bold.

Over this period, increases in gape width and swimming speed (Lauder and Di Santo, 2015) concomitant with body size and changes in tooth morphology (Cullen and Marshall, 2019), may confer an advantage to their foraging success, leading to ontogenetic shifts in diet. When examining overall dietary metrics calculated for smaller vs. larger bull sharks in the present study, the importance of piscivore/invertivore ariid prey (Motta et al., 1995; Mendoza-Carranza, 2003) supplanted detritivore/planktivore clupeids (Castillo-Rivera et al., 1996; De Brabandere et al., 2009) and piscivore/invertivore sciaenids (Sheridan, 1979; Willis et al., 2015) in the diet of larger sharks. Nevertheless, changes in dietary composition were not necessarily accompanied by a shift toward higher trophic level taxa, and the observed shift was minor $(<20 \% \Delta$ IRI). In fact, detritivore/planktivore mugilid (Cardona, 2016) prey remained the dominant fish family in the diets of both size classes of sharks. Though bull sharks are expected to increase their consumption of large-bodied or higher trophic level prey (e.g., chondrichthyans, marine mammals) with ontogeny $(>\sim 150 \mathrm{~cm})$ (Cliff and Dudley, 1991; Werry et al., 2011; Tillett et al., 2014), no such shift was observed. While it is possible bull sharks in the nwGoM simply do not exhibit a shift to these larger prey taxa, it is more likely due to focused sampling of juvenile sharks in this study. The lack of larger, marine prey reported in the diet of bull sharks elsewhere (e.g., Carangidae, Scombridae, Elasmobranchii; (Clark and von Schmidt, 1965; Cliff and Dudley, 1991) may also be explained by the limited seasonal sampling in this study, as it is not known what prey juvenile bull sharks exploit when, during the winter months, they vacate or reduce their use of estuaries in the GoM. Ontogenetic shifts in diet were not found to be statistically significant when testing for differences among individual-based estimates of dietary metrics. 


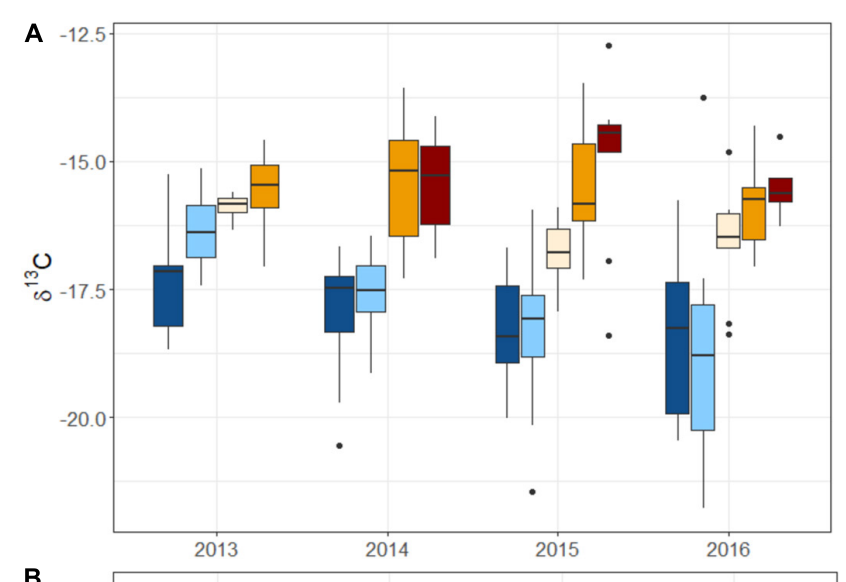

B

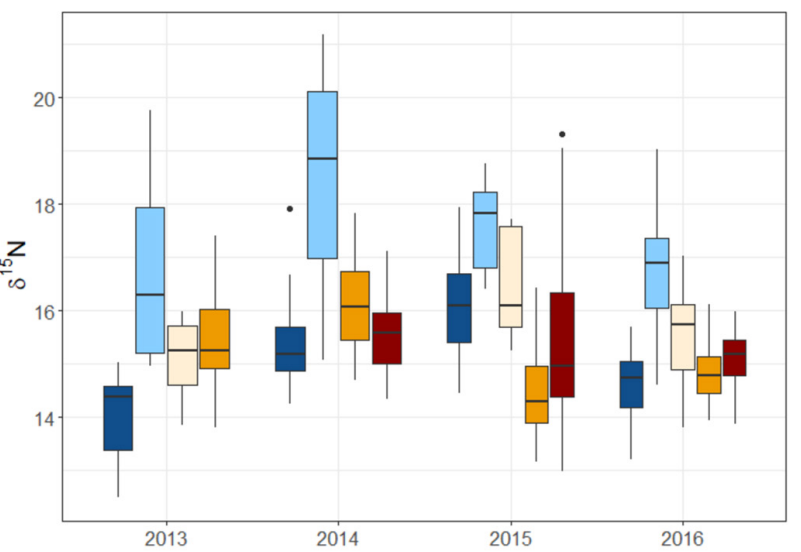

Bay

Sabine Lake

白 Galveston Bay

追 Matagorda Bay

追 Aransas Bay

- Corpus Christi Bay

C

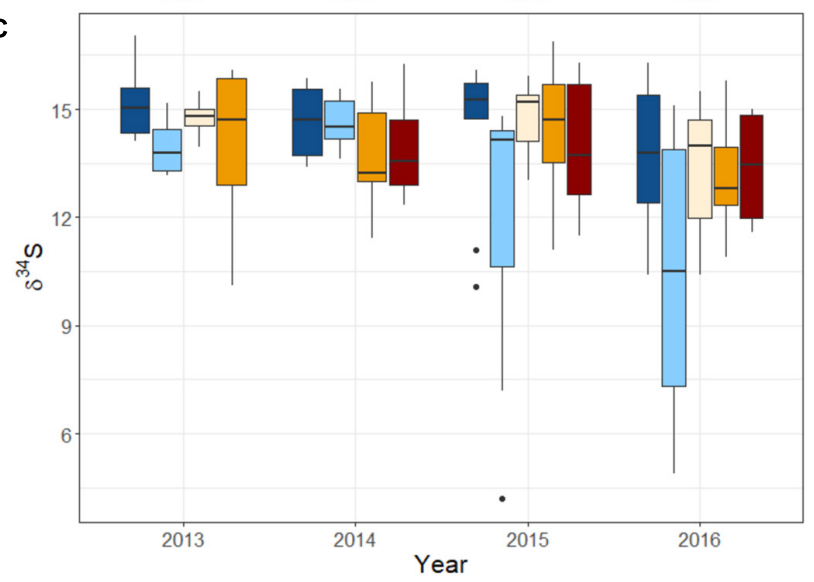

FIGURE 4 | Boxplots of stable isotope (A) $\delta^{13} \mathrm{C}$, (B) $\delta^{15} \mathrm{~N}$, (C) $\delta^{34} S$ delta values from juvenile bull sharks collected from estuaries (indicated by box shading) in the nwGoM between 2013 and 2016. Horizontal bars in each box represent median values, box margins represent the first and third quartiles, and whiskers approximate the $95 \%$ confidence interval of values.

The opportunistic nature of bull shark feeding and likely patchy prey distributions across Texas estuaries may have driven the high individual variation in stomach contents, and obscuring ontogenetic patterns. Although a greater number of samples may not be necessary to characterize the overall diet of sharks in this region, larger sample sizes may yet be required to clearly describe ontogenetic shifts in diet.

Across the size range of sharks sampled (549-1183 mm FL), ontogenetic shifts in trophic level and food web occupancy along the freshwater-marine continuum were indicated by significant shifts in $\delta^{13} \mathrm{C}$ (decrease), $\delta^{15} \mathrm{~N}$ (increase) and $\delta^{34} \mathrm{~S}$ (decrease) values with shark size. However, the sizes of ingested prey were not estimated here, and it remains unclear whether increases in $\delta^{15} \mathrm{~N}$ values with ontogeny reflect shifts in prey size or prey trophic level, growth/metabolism related shifts in nitrogen fractionation rates (Wyatt et al., 2018; Marcus et al., 2019), or a combination thereof. Though sharks exhibited ontogenetic decreases in their consumption of clupeids (pelagic planktivores), 


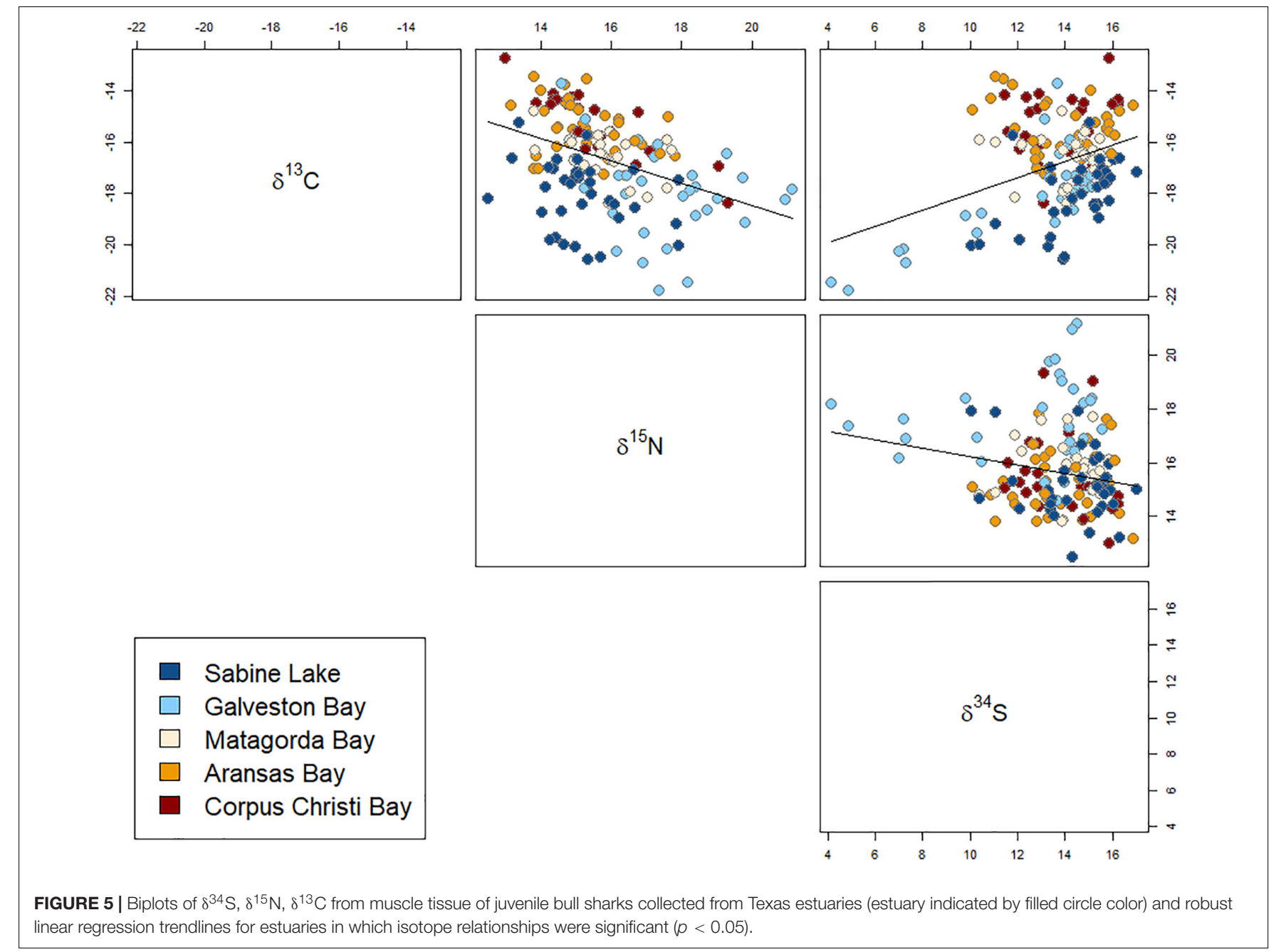

and corresponding increases in consumption of ariids (benthic piscivores and invertivores), these shifts were relatively small, and may be associated with the lack of significant shift in $\delta^{34} \mathrm{~S}$ with ontogeny. Ontogenetic changes in diet may also occur in tandem with habitat shifts, where sharks expand or shift their dietary niche to include prey encountered in new habitats (Grubbs, 2010).

Salinity is considered to be a key factor driving $\delta^{13} \mathrm{C}$ and $\delta^{34} \mathrm{~S}$ values in aquatic food webs (Peterson, 1999), and this was supported in the present study by the observed spatiotemporal trends in both isotopes. Latitudinal gradients in stable isotopes were identified, likely driven by corresponding shifts in primary producer assemblages, and environmental factors influencing the isotopic composition of carbon, nitrogen, and sulfur available to primary producers and higher-level consumers (i.e., sharks). Estuaries in south Texas are dominated by seagrasses (e.g., Thalassia testudinum, Halodule wrightii), while northern estuaries (Sabine Lake and Galveston Bay) contain limited abundances of these primary producers (Adair et al., 1994). Seagrasses are enriched in ${ }^{13} \mathrm{C}$ relative to other estuarine primary producers (Fry and Parker, 1979), which may explain the increase in $\delta^{13} \mathrm{C}$ values when moving from north to south. Increased rates of precipitation occurring in northern Texas estuaries presumably increase the inflow of freshwater depleted in ${ }^{13} \mathrm{C}$, which may serve to further decrease $\delta^{13} \mathrm{C}$ values in northern estuaries, compared to those in the south. Though $\delta^{13} \mathrm{C}$ values in sharks from southern estuaries were consistent across years, between 2013 and 2016, values decreased and became more variable in sharks from northern estuaries, which may have been driven by increased freshwater input in northern estuaries in 2015 and 2016 (Texas Water Development Board, 2020). Similarly, a positive relationship between $\delta^{13} \mathrm{C}$ and $\delta^{34} \mathrm{~S}$ values in the present study was observed exclusively in northern estuaries. This is unsurprising, as low values of both isotopes are often associated with primary producers or food webs occurring in freshwater habitats (Peterson and Fry, 1987; Fry and Chumchal, 2011). We saw no clear latitudinal gradient in $\delta^{15} \mathrm{~N}$ values, though sharks from Galveston Bay had consistently elevated $\delta^{15} \mathrm{~N}$ values compared to other estuaries in each year. The size range of sharks did not differ significantly among estuaries, so sharks in all estuaries were presumed to be of similar ontogenetic status. It is possible that sharks in Galveston Bay simply fed at a higher trophic level than those from other estuaries, though we detected no significant differences in dietary 
TABLE 4 | Pairwise robust regression results for stable isotopes from muscle tissue of juvenile bull sharks collected from nwGoM estuaries.

\begin{tabular}{|c|c|c|c|c|}
\hline Tracers & Estuary & $t$-value & $R^{2}$ & $p$-value \\
\hline \multirow[t]{6}{*}{$\delta^{13} C \sim \delta^{34} S$} & All & 3.50 & 0.117 & 0.001 \\
\hline & Sabine Lake & 7.74 & 0.406 & $<0.001$ \\
\hline & Galveston Bay & 15.10 & 0.796 & $<0.001$ \\
\hline & Matagorda Bay & -1.21 & 0.021 & 0.240 \\
\hline & Aransas Bay & -0.72 & 0.007 & 0.478 \\
\hline & Corpus Christi Bay & 1.41 & 0.027 & 0.174 \\
\hline \multirow[t]{6}{*}{$\delta^{15} N \sim \delta^{13} C$} & All & -5.28 & 0.167 & $<0.001$ \\
\hline & Sabine Lake & -1.33 & 0.034 & 0.191 \\
\hline & Galveston Bay & -1.79 & 0.035 & 0.084 \\
\hline & Matagorda Bay & -2.52 & 0.202 & 0.019 \\
\hline & Aransas Bay & -1.75 & 0.061 & 0.090 \\
\hline & Corpus Christi Bay & -7.33 & 0.756 & $<0.001$ \\
\hline \multirow[t]{6}{*}{$\delta^{15} N \sim \delta^{34} S$} & All & -3.54 & 0.048 & $<0.001$ \\
\hline & Sabine Lake & -0.24 & 0.000 & 0.811 \\
\hline & Galveston Bay & 0.22 & 0.000 & 0.827 \\
\hline & Matagorda Bay & 0.11 & 0.000 & 0.916 \\
\hline & Aransas Bay & 0.62 & 0.000 & 0.539 \\
\hline & Corpus Christi Bay & -2.89 & 0.186 & 0.009 \\
\hline
\end{tabular}

Significant results shown in bold.

composition among estuaries, which may be due in part to the limited taxonomic resolution of stomach contents identification. Nevertheless, elevated $\delta^{15} \mathrm{~N}$ values in Galveston Bay sharks may be alternatively explained by increased levels of urbanization and anthropogenic nitrogen $\left({ }^{15} \mathrm{~N}\right.$-enriched) input into Galveston Bay compared to other estuaries on the Texas coast (Holt and Ingall, 2000; Barcenas, 2013).

Though limited in geographic and trophic scope, some comparisons can be made with published isotope values from other estuarine consumers in the nwGoM. In a characterization of trophic relationships in a sub-bay of the Matagorda Bay estuary, among the highest $\delta^{15} \mathrm{~N}$ values reported by Akin and Winemiller (2008) ranged from 13.2 to $14.7 \%$, and belonged to small- to large-bodied teleosts (e.g., Gulf menhaden (Brevoortia patronus), red drum (Sciaenops ocellatus), gafftopsail catfish (Ariopsis felis), and alligator gar (Atractosteus spatula)). Bull sharks from Matagorda Bay in the present study had $\delta^{15} \mathrm{~N}$ values of $\sim 15-17 \%$, placing this species approximately one trophic level above other estuarine consumers. In addition to bull sharks, blacktip sharks (Carcharhinus limbatus) are among the most commonly encountered shark species in nwGoM estuaries (Plumlee et al., 2018). Published values of $\delta^{13} \mathrm{C}(\sim-16 \%)$ and $\delta^{15} \mathrm{~N}(\sim 16.5 \%)$ from blacktip sharks captured along the northern and central Texas coast (Plumlee and Wells, 2016; Matich et al., $2021)$ compared with those in the present study $\left(\delta^{13} \mathrm{C}: \sim-17 \%\right.$; $\delta^{15} \mathrm{~N} \sim 16 \%$ ) suggest that bull sharks occupy similar or higher trophic positions as blacktips. Given the similarity in trophic positions implied by similar $\delta^{15} \mathrm{~N}$ values, slightly diminished values of $\delta^{13} \mathrm{C}$ in bull sharks may indicate this species exploits ${ }^{13} \mathrm{C}$ depleted freshwater/brackish food webs to a greater extent than blacktips. This is supported by direct comparisons of bull and blacktip shark habitat use (Matich et al., 2020), and may exist as a form of niche partitioning in which bull sharks exploit their tolerance for low salinities to mitigate potential competition with blacktips or other stenohaline piscivores (Dwyer et al., 2020).

Carcharhinid sharks develop their offspring in utero where they are nourished via yolk-sac placenta and, at parturition, the isotopic composition of the offspring reflects that of their mother (Hussey et al., 2010). Post-parturition, sharks retain maternal isotope ratios during a turnover period (555-786 days for $\delta^{13} \mathrm{C}$ in white muscle; Logan and Lutcavage, 2010) during which their tissues become increasingly reflective of their diet. As the majority of sharks included in our analyses were YOYs, the observed isotopic values are expected to represent maternally derived isotope ratios, if only partially (Olin et al., 2011; Belicka et al., 2012). This may provide an alternative explanation for slightly elevated $\delta^{13} \mathrm{C}$ values in smaller (presumably younger) sharks, if these values decreased with age as juveniles begin to integrate the isotopic composition of their prey. However, it becomes difficult to explain the significant increase in $\delta^{15} \mathrm{~N}$ values with ontogeny if maternal signatures are indeed present in the tissue of YOY sharks in this study. Adult female bull sharks almost certainly occupy a higher trophic position than their juvenile offspring, thus neonatal sharks should exhibit an overall decrease in $\delta^{15} \mathrm{~N}$ values with age (and by extension, size), as maternal $\delta^{15} \mathrm{~N}$ values eventually begin to reflect the juveniles' prey. Estimated turnover rates of $\delta^{15} \mathrm{~N}$ in white muscle of C. plumbeus range from 340 to 457 days (Logan and Lutcavage, 2010), in which case YOYs (which comprised the majority of sampled sharks), should still exhibit maternal $\delta^{15} \mathrm{~N}$ values. The apparent lack of maternal influence in $\delta^{15} \mathrm{~N}$ values may be explained if adult females occupied food webs depleted in ${ }^{15} \mathrm{~N}$ while carrying offspring, after which, juvenile sharks began foraging in ${ }^{15} \mathrm{~N}$-enriched food webs in nursery habitats. In such a case, losses of the ${ }^{15} \mathrm{~N}$ depleted maternal signal would be difficult to differentiate from increases in $\delta^{15} \mathrm{~N}$ values arising from ontogenetic increases in trophic position.

\section{Future Directions}

Given the patterns of spatiotemporal variability of isotopes in this study, future studies seeking to estimate trophic position of consumers in nwGoM estuaries should perform time-matched collections of a representative suite of primary producers across the freshwater-marine continuum. Sampling efforts including a greater proportion of subadult bull sharks would provide better representation of ontogenetic shifts occurring later in the life of this coastal elasmobranch. Nevertheless, where high levels of overlap exist in the isotopic niche of diverse estuarine food webs (e.g., Winemiller et al., 2007), the application of isotope mixing models may not effectively estimate prey-specific contributions to the diet of a top predator such as the bull shark. Direct examination of stomach contents coupled with stable isotope analysis represents a powerful approach for identifying ontogenetic shifts in dietary composition or among disparate aquatic food webs, and such results may readily incorporate into ecosystem-based models and their attendant management strategies. 


\section{DATA AVAILABILITY STATEMENT}

The raw data supporting the conclusions of this article will be made available by the authors, without undue reservation.

\section{ETHICS STATEMENT}

The animal study was reviewed and approved by Texas A\&M University Institutional Animal Care and Use Committee.

\section{AUTHOR CONTRIBUTIONS}

Both authors conceived the study. TT collected and analyzed isotope and stomach content data, and led writing of the text and preparation of tables and figures with input from RW.

\section{FUNDING}

This work was based on a dissertation submitted to Texas A\&M University. Funds for this study were provided by the Texas Sea Grant Grants-In-Aid of Graduate Research Scholarship.

\section{REFERENCES}

Adair, S. E., Moore, J. L., and Onuf, C. P. (1994). Distribution and status of submerged vegetation in estuaries of the upper texas coast. Wetlands 14, 110-121. doi: 10.1007/BF03160627

Akin, S., and Winemiller, K. O. (2008). Body size and trophic position in a temperate estuarine food web. Acta Oecol. 33, 144-153. doi: 10.1016/j.actao. 2007.08.002

Barcenas, D. L. (2013). Use of Stable Isotope Analyses to Describe Trophic Dynamics of Aquatic Ecosystems in Galveston Bay, Texas. Ph.D. thesis. Houston, TX: University of Houston-Clear Lake.

Belicka, L. L., Matich, P., Jaffé, R., and Heithaus, M. R. (2012). Fatty acids and stable isotopes as indicators of early-life feeding and potential maternal resource dependency in the bull shark Carcharhinus leucas. Mar. Ecol. Prog. Ser. 455, 245-256. doi: 10.3354/meps09674

Bizzarro, J. J., Robinson, H. J., Rinewalt, C. S., and Ebert, D. A. (2007). Comparative feeding ecology of four sympatric skate species off central California, USA. Environ. Biol. Fishes 80, 197-220. doi: 10.1007/s10641-007-9241-6

Cardona, L. (2016). "Food and feeding of mugilidae," in Biology, Ecology and Culture of Grey Mullets (Mugilidae), eds D. Crosseti and S. J. Blaber (Boca Raton, FL: CRC Press), 165-195.

Castillo-Rivera, M., Kobelkowsky, A., and Zamayoa, V. (1996). Food resource partitioning and trophic morphology of Brevoortia gunteri and B. patronus. J. Fish. Biol. 49, 1102-1111. doi: 10.1111/j.1095-8649.1996.tb01781.x

Clark, E., and von Schmidt, K. (1965). Sharks of the Central Gulf Coast of Florida. Bull. Mar. Sci. 15, 13-83.

Cliff, G., and Dudley, S. F. J. (1991). Sharks caught in the protective gill nets of Natal, South Africa. 4. The bull shark Carcharhinus leucas Valenciennes. South Afr. J. Mar. Sci. 10, 253-270. doi: 10.2989/02577619109504636

Cortés, E. (1997). A critical review of methods of studying fish feeding based on analysis of stomach contents: application to elasmobranch fishes. Can. J. Fish. Aquat. Sci. 54, 726-738. doi: 10.1139/f96-316

Cottrant, E., Matich, P., and Fisher, M. (2021). Boosted regression tree models predict the diets of juvenile bull sharks in a subtropical estuary. Mar. Ecol. Prog. Ser. 659, 127-141. doi: 10.3354/meps 13568

Crowder, L., and Norse, E. (2008). Essential ecological insights for marine ecosystem-based management and marine spatial planning. Mar. Policy 32, 772-778. doi: 10.1016/j.marpol.2008.03.012

\section{ACKNOWLEDGMENTS}

We thank M. Fisher, C. Gelpi, J. Mambretti, W. Bubley, L. Hartman, B. Bartram, C. Mace, M. Fisher, D. York, A. Adams, and others from the Texas Parks and Wildlife Department for collecting and providing access to samples. We also thank J. Rooker, C. Marshall, and B. Sterba-Boatwright for many constructive discussions and for providing feedback on an early draft of the manuscript. We extend our thanks to those who provided access to laboratory equipment and technical guidance: J. Plumlee, T. Richards, A. Armitage, C. Iseton, M. Dance, and P. Matich. We would like to thank volunteers who assisted with sample processing and preparation: J. Bowling, K. Walker, P. Faulkner, and D. Webb, J. Kubacak. We also thank two reviewers for their constructive feedback and suggestions that greatly improved the manuscript.

\section{SUPPLEMENTARY MATERIAL}

The Supplementary Material for this article can be found online at: https://www.frontiersin.org/articles/10.3389/fmars. 2021.664316/full\#supplementary-material

Cullen, J. A., and Marshall, C. D. (2019). Do sharks exhibit heterodonty by tooth position and over ontogeny? A comparison using elliptic Fourier analysis. J. Morphol. 280, 687-700. doi: 10.1002/jmor.20975

Daly, R., Froneman, P. W., and Smale, M. J. (2013). Comparative feeding ecology of bull sharks (Carcharhinus leucas) in the coastal waters of the southwest Indian Ocean inferred from stable isotope analysis. PLoS One 8:e78229. doi: 10.1371/journal.pone.0078229

De Brabandere, L., Catalano, M. J., Frazer, T. K., and Allen, M. S. (2009). Stable isotope evidence of ontogenetic changes in the diet of gizzard shad Dorosoma cepedianum. J. Fish. Biol. 74, 105-119. doi: 10.1111/j.1095-8649.2008.02114.x

Dwyer, R. G., Campbell, H. A., Cramp, R. L., Burke, C. L., Micheli-Campbell, M. A., Pillans, R. D., et al. (2020). Niche partitioning between river shark species is driven by seasonal fluctuations in environmental salinity. Funct. Ecol. 34, 2170-2185. doi: 10.1111/1365-2435.13626

Froeschke, J., Stunz, G. W., and Wildhaber, M. L. (2010). Environmental influences on the occurrence of coastal sharks in estuarine waters. Mar. Ecol. Prog. Ser. 407, 279-292. doi: 10.3354/meps08546

Fry, B., and Chumchal, M. M. (2011). Sulfur stable isotope indicators of residency in estuarine fish. Limnol. Oceanogr. 56, 1563-1576. doi: 10.4319/lo.2011.56.5. 1563

Fry, B., and Parker, P. L. (1979). Animal diet in Texas seagrass meadows: $\delta 13 \mathrm{C}$ evidence for the importance of benthic plants. Estuar. Coast. Mar. Sci. 8, 499-509. doi: 10.1016/0302-3524(79)90031-8

Grubbs, R. D. (2010). “Ontogenetic shifts in movements and habitat use," in Sharks and Their Relatives II: Biodiversity, Adaptive Physiology, and Conservation, eds J. F. Carrier, J. A. Musick, and M. R. Heithaus (Boca Raton, FL: CRC Press), 335-366.

Heupel, M. R., and Simpfendorfer, C. A. (2011). Estuarine nursery areas provide a low-mortality environment for young bull sharks Carcharhinus leucas. Mar. Ecol. Prog. Ser. 433, 237-244. doi: 10.3354/meps09191

Heupel, M. R., Yeiser, B. G., Collins, A. B., Ortega, L., and Simpfendorfer, C. A. (2010). Long-term presence and movement patterns of juvenile bull sharks, Carcharhinus leucas, in an estuarine river system. Mar. Freshw. Res. 61, 1-10. doi: 10.1071/MF09019

Holt, S. A., and Ingall, E. D. (2000). Preliminary Report: Carbon and Nitrogen Sources Supporting Food Webs of Spotted Sea Trout in Galveston Bay and the Laguna Madre. Management Data Series Number 172. Austin, TX: Texas Parks and Wildlife Department. 
Hussey, N. E., MacNeil, M. A., Olin, J. A., McMeans, B. C., Kinney, M. J., Chapman, D. D., et al. (2012). Stable isotopes and elasmobranchs: tissue types, methods, applications and assumptions. J. Fish. Biol. 80, 1449-1484. doi: 10.1111/j.10958649.2012.03251.x

Hussey, N. E., Wintner, S. P., Dudley, S. F. J., Cliff, G., Cocks, D. T., and MacNeil, M. A. (2010). Maternal investment and size-specific reproductive output in carcharhinid sharks. J. Anim. Ecol. 79, 184-193. doi: 10.1111/J.1365-2656.2009. 01623.X

Hyslop, E. J. (1980). Stomach contents analysis-a review of methods and their application. J. Fish. Biol. 17, 411-429. doi: 10.1111/j.1095-8649.1980.tb02 775.x

Lauder, G. V., and Di Santo, V. (2015). "Swimming mechanics and energetics of elasmobranch fishes," in Fish Physiology, Vol. 34, eds R. E. Shadwick, A. P. Farrell, and C. J. Brauner (New York, NY: Academic Press), 219-253. doi: 10.1016/b978-0-12-801289-5.00006-7

Leigh, S. C., Papastamatiou, Y. P., and German, D. P. (2018). Seagrass digestion by a notorious “carnivore." Proc. R. Soc. B. Biol. Sci. 285:20181583. doi: 10.1098/ rspb. 2018.1583

Logan, J., and Lutcavage, M. (2010). Stable isotope dynamics in elasmobranch fishes. Hydrobiologia 644, 231-244. doi: 10.1007/s10750-0100120-3

Marcus, L., Virtue, P., Nichols, P. D., Ferreira, L. C., Pethybridge, H., and Meekan, M. G. (2019). stable isotope analysis of dermis and the foraging behavior of Whale Sharks at Ningaloo Reef, Western Australia. Front. Mar. Sci. 6:546. doi: 10.3389/fmars.2019.00546

Martinez-Andrade, F., Fisher, M., Bowling, B., and Balboa, B. (2009). Marine Resource Monitoring Operations Manual. Austin, TX: Texas Parks and Wildlife Department.

Matich, P., and Heithaus, M. R. (2014). Multi-tissue stable isotope analysis and acoustic telemetry reveal seasonal variability in the trophic interactions of juvenile bull sharks in a coastal estuary. J. Anim. Ecol. 83, 199-213. doi: 10.1111/ 1365-2656.12106

Matich, P., Nowicki, R. J., Davis, J., Mohan, J. A., Plumlee, J. D., Strickland, B. A., et al. (2020). Does proximity to freshwater refuge affect the size structure of an estuarine predator (Carcharhinus leucas) in the north-western Gulf of Mexico? Mar. Freshw. Res. 71, 1501-1516. doi: 10.1071/MF19346

Matich, P., Plumlee, J. D., Weideli, O. C., and Fisher, M. (2021). New insights into the trophic ecology of blacktip sharks (Carcharhinus limbatus) from a subtropical estuary in the western Gulf of Mexico. J. Fish. Biol. 98, 470-484. doi: $10.1111 /$ jfb.14592

Mendoza-Carranza, M. (2003). The feeding habits of gafftopsail catfish Bagre marinus (Ariidae) in Paraiso Coast, Tabasco, Mexico. Hidrobiológica 13, 119126.

Motta, P. J., Clifton, K. B., Hernandez, P., Eggold, B. T., Giordano, S. D., and Wilcox, R. (1995). Feeding relationships among nine species of seagrass fishes of Tampa Bay, Florida. Bull. Mar. Sci. 56, 185-200.

Olin, J. A., Hussey, N. E., Fritts, M., Heupel, M. R., Simpfendorfer, C. A., Poulakis, G. R., et al. (2011). Maternal meddling in neonatal sharks: Implications for interpreting stable isotopes in young animals. Rapid Commun. Mass Spectrom. 25, 1008-1016. doi: 10.1002/rcm.4946

Papastamatiou, Y. P., Lowe, C. G., Caselle, J. E., and Friedlander, A. M. (2009). Scale-dependent effects of habitat on movements and path structure of reef sharks at a predator-dominated atoll. Ecology 90, 996-1008. doi: 10.1890/080491.1

Peterson, B. J. (1999). Stable isotopes as tracers of organic matter input and transfer in benthic food webs: a review. Acta Oecol. 20, 479-487. doi: 10.1016/S1146609X(99)00120-4

Peterson, B. J., and Fry, B. (1987). Stable isotopes in ecosystem studies. Annu. Rev. Ecol. Syst. 18, 293-320. doi: 10.1146/annurev.es.18.110187.00 1453

Pinkas, L., Oliphant, M. S., and Iverson, I. L. K. (1971). Food Habits of Albacore, Bluefin Tuna and Bonito in Californian Waters. Sacramento, CA: California Department of Fish and Wildlife.

Plumlee, J. D., Dance, K. M., Matich, P., Mohan, J. A., Richards, T. M., TinHan, T. C., et al. (2018). Community structure of elasmobranchs in estuaries along the northwest Gulf of Mexico. Estuar. Coast. Shelf Sci. 204, 103-113. doi: 10. 1016/j.ecss.2018.02.023
Plumlee, J. D., and Wells, R. J. D. (2016). Feeding ecology of three coastal shark species in the northwest Gulf of Mexico. Mar. Ecol. Prog. Ser. 550, 163-174. doi: $10.3354 /$ meps 11723

Rousseeuw, P., Croux, C., Todorov, V., Ruckstuhl, A., Salibian-barrera, M., Verbeke, T., et al. (2015). Package 'robustbase.' Basic Robust Statistics. R Package Version 0.92-5.

Sadowsky, V. (1971). Notes on the bull shark Carcharhinus leucas in the lagoon region of Canaeia, Brazil. Bol. Inst. Oceanogr. 20, 71-78. doi: 10.1590/s037355241971000200002

Sheridan, P. F. (1979). Trophic resource utilization by three species of sciaenid fishes in a northwest Florida estuary. Northeast Gulf Sci. 3, 1-15. doi: 10.18785/ negs.0301.01

Snelson, F. F., Mulligan, T. J., and Williams, S. E. (1984). Food habits, occurrence, and population structure of the bull shark, Carcharhinus leucas, in Florida coastal lagoons. Bull. Mar. Sci. 34, 71-80.

Texas Water Development Board (2020). Hydrological Data for the Texas Coast. Available online at: https://waterdatafortexas.org/coastal/hydrology (accessed Mar 20, 2020).

Thorburn, D. C., Morgan, D. L., Rowland, A. J., and Gill, H. (2004). Elasmobr anchs in the Fitzroy River, Western Australia. Perth: Report to the Natural Heritage Trust.

Tillett, B. J., Meekan, M. G., and Field, I. C. (2014). Dietary overlap and partitioning among three sympatric carcharhinid sharks. Endanger. Species Res. 25, 283-293. doi: 10.3354/esr00615

TinHan, T. C. (2020). Population and Trophic Connectivity of Bull Sharks in the Northwestern Gulf of Mexico. College Station, TX: Texas A\&M University.

Trystram, C., Rogers, K. M., Soria, M., and Jaquemet, S. (2016). Feeding patterns of two sympatric shark predators in coastal ecosystems of an oceanic island. Can. J. Fish. Aquat. Sci. 74, 216-227. doi: 10.1139/cjfas-2016-0105

Tuma, R. E. (1976). An investigation of the feeding habits of the bull shark, Carcharhinus leucas, in the Lake Nicaragua-Rio San Juan System. Investig. Ichthyofauna Nicar Lakes 39, 533-538.

van Zinnicq Bergmann, M. P. M., Postaire, B. D., Gastrich, K., Heithaus, M. R., Hoopes, L. A., Lyons, K., et al. (2021). Elucidating shark diets with DNA metabarcoding from cloacal swabs. Mol. Ecol. Resour. 21, 1056-1067. doi: 10. 1111/1755-0998.13315

Werry, J. M., Lee, S. Y., Otway, N. M., Hu, Y., and Sumpton, W. (2011). A multifaceted approach for quantifying the estuarine-nearshore transition in the life cycle of the bull shark, Carcharhinus leucas. Mar. Freshw. Res. 62, 1421-1431. doi: $10.1071 /$ MF11136

Willis, C. M., Richardson, J., Cowan, J., and Biondo, P. (2015). Diet composition, feeding strategy, and diet overlap of 3 sciaenids along the southeastern United States. Fish. Bull. 113, 290-301. doi: 10.7755/fb.113.3.5

Winemiller, K. O., Akin, S., and Zeug, S. C. (2007). Production sources and food web structure of a temperate tidal estuary: integration of dietary and stable isotope data. Mar. Ecol. Prog. Ser. 343, 63-76. doi: 10.3354/meps06884

Wyatt, A. S. J., Matsumoto, R., Chikaraishi, Y., Miyairi, Y., Yokoyama, Y., Sato, K., et al. (2018). Enhancing insights into foraging specialization in the world's largest fish using a multi-tissue, multi-isotope approach. Ecol. Monogr. 89:e01339. doi: 10.1002/ecm.1339

Conflict of Interest: The authors declare that the research was conducted in the absence of any commercial or financial relationships that could be construed as a potential conflict of interest.

Publisher's Note: All claims expressed in this article are solely those of the authors and do not necessarily represent those of their affiliated organizations, or those of the publisher, the editors and the reviewers. Any product that may be evaluated in this article, or claim that may be made by its manufacturer, is not guaranteed or endorsed by the publisher.

Copyright (c) 2021 TinHan and Wells. This is an open-access article distributed under the terms of the Creative Commons Attribution License (CC BY). The use, distribution or reproduction in other forums is permitted, provided the original author(s) and the copyright owner(s) are credited and that the original publication in this journal is cited, in accordance with accepted academic practice. No use, distribution or reproduction is permitted which does not comply with these terms. 